\title{
Butter Composition and Texture from Cows with Different Milk Fatty Acid Compositions Fed Fish Oil or Roasted Soybeans ${ }^{1}$
}

\author{
G. Bobe, ${ }^{\star 2}$ S. Zimmerman, ${ }^{\star} \dagger$ E. G. Hammond,† A. E. Freeman, ${ }^{\star}$ P. A. Porter, $\ddagger$ C. M. Luhman, $\neq$ \\ and D. C. Beitz ${ }^{\star 3}$ \\ *Department of Animal Science, and \\ †Department of Food Science and Human Nutrition, lowa State University, Ames 50011 \\ ‡LongView Animal Nutrition Center, Gray Summit, MO 63039
}

\begin{abstract}
Changing the milk fatty acid composition can improve the nutritional and physical properties of dairy products and their acceptability to consumers. A more healthful milk fatty acid composition can be achieved by altering the cow's diet, for example, by feeding supplemental fish oil (FO) or roasted soybeans (RSB), or by selecting cows with a more unsaturated milk fatty acid composition. We examined whether feeding supplemental FO or RSB to cows that had a more unsaturated milk fatty acid composition acted additively to produce butter with improved fatty acid composition and texture. Using a $3 \times 3$ Latin square design with 2 replications, we fed diets to multiparous Holstein cows (60 to 200 DIM) chosen for producing either more or less unsaturated milk fatty acid composition ( $\mathrm{n}=6$ for each group) for three 3 -wk periods. The control diet contained $3.7 \%$ crude fat and the 2 experimental diets contained, on a dry matter basis, $0.8 \%$ of additional lipids in the form of $0.9 \%$ of FO or $5 \%$ of RSB. The milk, collected in the third week of feeding, was used to make butter, which was analyzed for its fatty acid composition and physical properties. Dry matter intake, milk yield, and milk composition were not significantly affected by cow diet or by cow selection. Cows that produced a more unsaturated and healthful milk fat prior to the feeding study, according to a "health-promoting index" [HPI $=$ ( sum of \% of unsaturated fatty acids $) /$ $(\% 12: 0+4 \times \% 14: 0+\% 16: 0)]$, maintained a higher HPI in their butter during the feeding study than did cows with a low HPI. Milk from cows fed supplemental FO

\footnotetext{
Received December 21, 2006.

Accepted January 31, 2007.

${ }^{1}$ Publication of the Iowa Agriculture and Home Economics Experi-

${ }^{2}$ Present address: Cancer Prevention Fellowship Program, Divi-
} ment Station, Ames, Project Number 3801. A preliminary report was presented in J. Dairy Sci. 86(Suppl. 1):44. sion of Cancer Prevention, National Cancer Institute, National Institutes of Health, Frederick, MD 21702.

${ }^{3}$ Corresponding author: dcbeitz@iastate.edu
\end{abstract}

or RSB yielded more unsaturated butters with a higher HPI. This butter also was softer when the cows were fed RSB. Feeding RSB to cows chosen for their high milk HPI yielded the most unsaturated butter with the highest HPI and softest texture. Thus, selecting cows with a more health-promoting milk fatty acid composition and feeding supplemental RSB can be used in combination to produce butter that has a consumer-friendly texture and a healthful fatty acid profile.

Key words: butter texture, dairy cow, diet, fatty acid composition

\section{INTRODUCTION}

Milk fat, which is 97 to $98 \%$ triacylglycerols, is a source of energy and nutrients and an important food ingredient that provides desirable textural and flavor characteristics (Jensen, 2002). The fatty acid composition of milk fat typically comprises $70 \%$ saturated fatty acids, $25 \%$ monounsaturated fatty acids, and 5\% polyunsaturated fatty acids (Grummer, 1991). The carbon number of the fatty acids, their degree of unsaturation, and their positional distribution within the triacylgycerol molecules influence the nutritional and physical properties and consumer acceptance of foods containing milk fat (Hillbrick and Augustin, 2002).

The high ratio of saturated to unsaturated fatty acids in milk fat has been a concern because of the link between intake of saturated fatty acids and various biological markers for cardiovascular disease risk, such as elevated blood pressure, insulin resistance, and hyperlipidemia, particularly of low-density lipoprotein cholesterol (Vessby et al., 2001; Sacks and Katan, 2002; Mensink et al., 2003; Rasmussen et al., 2006). Specifically, greater consumption of myristic acid (14:0), palmitic acid (16:0), and lauric acid (12:0) increases concentrations of low-density lipoprotein, whereas greater consumption of unsaturated fatty acids has the reverse effect (Mensink et al., 2003; Fernandez and West, 2005). Ulbricht and Southgate (1991) proposed an atherogenic index for dietary fats, which is the sum of concentra- 
tions of $12: 0,16: 0$, and $4 \times 14: 0$ divided by the sum of concentrations of unsaturated fatty acids, as a risk indicator for cardiovascular diseases. We termed the inverse of the atherogenic index the health-promoting index (HPI; Chen et al., 2004).

Butter has a desirable flavor and is regarded as "natural" by consumers. The image of butter can be further improved by making it more spreadable at refrigeration temperatures (Hillbrick and Augustin, 2002; Henning et al., 2006). Modifying the fatty acid composition of butter by decreasing the proportions of 12:0, 14:0, 16:0, and stearic acid (18:0) and increasing the proportions of unsaturated and short-chain fatty acids improves its spreadability. Such changes can be achieved by processing technologies such as milk fat fractionation (Kaylegian, 1999; Henning et al., 2006), by cow nutrition, or by cow selection. Cow nutrition and selection approaches have the advantage that they retain the natural image and delicate flavor of butter (Hillbrick and Augustin, 2002). Feeding cows supplemental fish oil (Baer et al., 2001; Ramaswamy et al., 2001) or soybean products (Banks et al., 1980; Murphy et al., 1990; Ramaswamy et al., 2001) are common nutritional approaches to achieving less saturated and more spreadable butters. Our group demonstrated that segregating the milk of cows with a high HPI milk fatty acid composition yielded dairy products, including butter, with a more unsaturated fatty acid composition that were softer and had a satisfactory flavor (Bobe et al., 2003; Chen et al., 2004). The combination of cow nutrition and selection to improve the fatty acid composition and textural properties of dairy products has not been tested. Thus, the objective of this study was to test whether milk fatty acid composition could be improved further by feeding supplemental fish oil (FO) or roasted soybeans (RSB) to cows already producing a more health-promoting milk fatty acid composition. Would these variables act in an additive manner to produce butter with a more health-promoting fatty acid composition and a softer texture?

\section{MATERIALS AND METHODS}

\section{Experimental Design and Sample Collection}

A $3 \times 3$ Latin square design with 3 feeding periods of 3 wk was used for this study, which was conducted with one replication in summer and the other in fall of 2001 at the Iowa State University Dairy Breeding Research Facility (Ankeny, IA). Cows were chosen, managed, and treated in accordance with guidelines established by the Iowa State University Committee on Animal Care. For each replicate of the feeding study, we selected, from a new pool of 25 multiparous Holstein dairy cows (60 to $200 \mathrm{DIM}), 3$ cows with the lowest HPI and 3 cows with the highest HPI based on the fatty acid composition of their milk. Milk samples were collected 6 wk (first replicate) and $2 \mathrm{wk}$ (second replicate) prior to the feeding study and were frozen at $-20^{\circ} \mathrm{C}$ until analyzed. In the first replicate, cows selected for a low HPI had an HPI of between 0.33 and 0.35 , whereas cows selected for a high HPI had an HPI of between 0.56 and 0.78 . In the second replicate, cows selected for a low HPI had an HPI of between 0.25 and 0.27 , whereas cows selected for a high HPI had an HPI of between 0.34 and 0.39 .

Experimental diets were 1) a control diet, 2) the control diet supplemented with $0.9 \%$ (on a DM basis) of menhaden FO (Omega Protein, Hammond, LA), and 3) the control diet without fish meal supplemented with $5.0 \%$ (on DM basis) of cracked RSB. Details of the ingredient and chemical composition of the diets are provided in Table 1. Diets were formulated to meet nutrient requirements of dairy cows in early lactation according to the NRC (2001). The first 2 wk of each feeding period were used for adaptation to the diets, and the third week was used for data collection.

Cows were housed in a free-stall barn starting $1 \mathrm{wk}$ before the start of the feeding period, and Calan Broadbent feeder doors (American Calan, Inc., Northwood, $\mathrm{NH}$ ) were used to measure individual feed intakes. Cows were fed diets individually as a fresh TMR twice daily at 0500 and $1700 \mathrm{~h}$ ad libitum with continuous access to feed except during milking. Refused feed was removed prior to the evening feeding. Amounts fed and refused were recorded daily, and the average DMI for wk 3 of each feeding period was used for statistical analysis. One cow chosen for high-HPI milk fatty acid composition and fed the FO diet for $4 \mathrm{~d}$ became sick due to diet-unrelated causes and was removed from the experiment.

Cows were milked twice daily at 0500 and $1700 \mathrm{~h}$. Milk yield was recorded throughout the feeding study, and the average milk yield in wk 3 of each feeding period was calculated for statistical analyses. Milk samples were collected for $3 \mathrm{~d}$ during the last week of each feeding period and sent refrigerated at $4^{\circ} \mathrm{C}$ to Swiss Valley Farms (Davenport, IA) to be analyzed for fat, protein, lactose, total solids, and urea $\mathrm{N}$ by midinfrared spectrophotometry (MilkOScan 203, Foss Food Technology Corp., Eden Prairie, MN) and for SCC with a Fossomatic 90 (Foss Food Technology Corp.). The averages of the $3 \mathrm{~d}$ were used for statistical analysis.

\section{Butter Manufacture}

At the end of each feeding period, milk was collected for $1 \mathrm{~d}$ separately from each cow. Each milk sample was vat pasteurized at $63^{\circ} \mathrm{C}$ for $30 \mathrm{~min}$ with agitation in 
Table 1. Ingredient and nutrient composition of cow diets: control, fish oil (FO), or roasted soybeans (RSB)

\begin{tabular}{|c|c|c|c|}
\hline \multirow[b]{2}{*}{ Item } & \multicolumn{3}{|c|}{ Diet } \\
\hline & Control & FO & $\mathrm{RSB}$ \\
\hline & & of DM & 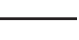 \\
\hline \multicolumn{4}{|l|}{ Ingredient } \\
\hline Alfalfa haylage & 14.24 & 14.11 & 14.23 \\
\hline Choice white grease & 0.83 & 0.83 & 0.83 \\
\hline Corn grain, ground & 15.60 & 15.46 & 16.78 \\
\hline Corn gluten feed & 8.18 & 8.11 & 5.73 \\
\hline Corn silage & 38.19 & 37.84 & 38.17 \\
\hline Fish meal & 1.11 & 1.10 & - \\
\hline Fish oil ${ }^{1}$ & - & 0.90 & - \\
\hline Roasted soybeans & - & - & 4.98 \\
\hline Soybean hulls & 6.61 & 6.55 & 5.63 \\
\hline Soybean meal, $48 \%$ CP & 9.54 & 9.45 & 7.89 \\
\hline Soy Pass ${ }^{2}$ & 2.48 & 2.46 & 2.48 \\
\hline Super $40^{3}$ & 1.80 & 1.78 & 1.80 \\
\hline Dicalcium phosphate & 0.49 & 0.49 & 0.49 \\
\hline Calcium carbonate & 0.31 & 0.31 & 0.38 \\
\hline Magnesium oxide & 0.08 & 0.08 & 0.08 \\
\hline Potassium chloride & 0.23 & 0.23 & 0.24 \\
\hline Sodium bicarbonate & 0.16 & 0.16 & 0.16 \\
\hline Sodium chloride & 0.08 & 0.08 & 0.08 \\
\hline Zinpro 4-plex ${ }^{4}$ & 0.02 & 0.02 & 0.02 \\
\hline Dairy micro premix $2 \mathrm{X}^{5}$ & 0.07 & 0.07 & 0.07 \\
\hline Selenium $600(600 \mathrm{ppm}$ of Se $)$ & 0.01 & 0.01 & 0.01 \\
\hline \multicolumn{4}{|l|}{ Chemical composition } \\
\hline $\mathrm{DM}, \%$ of diet & 55.83 & 56.05 & 55.86 \\
\hline $\mathrm{CP}$ & 18.46 & 18.30 & 18.40 \\
\hline RUP & 6.15 & 6.10 & 6.29 \\
\hline Crude fat & 3.66 & 4.52 & 4.50 \\
\hline $\mathrm{NE}_{\mathrm{L}}, \mathrm{Mcal} / \mathrm{kg}$ & 1.67 & 1.72 & 1.69 \\
\hline NDF & 33.79 & 33.49 & 32.88 \\
\hline $\mathrm{ADF}$ & 19.95 & 19.78 & 19.62 \\
\hline $\mathrm{NFC}^{6}$ & 38.06 & 37.72 & 38.62 \\
\hline $\mathrm{Ca}$ & 0.75 & 0.75 & 0.71 \\
\hline $\mathrm{P}$ & 0.50 & 0.50 & 0.47 \\
\hline $\mathrm{Mg}$ & 0.28 & 0.28 & 0.28 \\
\hline $\mathrm{Na}$ & 0.09 & 0.09 & 0.09 \\
\hline K & 1.38 & 1.37 & 1.41 \\
\hline $\mathrm{Cl}$ & 0.29 & 0.29 & 0.28 \\
\hline $\mathrm{S}$ & 0.22 & 0.22 & 0.21 \\
\hline
\end{tabular}

${ }^{1}$ Menhaden fish oil was donated by Omega Protein (Hammond, LA).

${ }^{2}$ Soy Pass is a product of Borregaard LignoTech (Rothschild, WI).

${ }^{3}$ Super 40 is a product of Quality Liquid Feeds (Hinton, IA).

${ }^{4}$ Zinpro 4-plex is a product of Zinpro Corporation (Eden Prairie, $\mathrm{MN}$ ) and contains $2.58 \%$ zinc, $1.43 \%$ manganese, $0.90 \%$ copper, $0.18 \%$ cobalt, $8.21 \%$ Met, $3.80 \%$ Lys, $11.5 \%$ protein, $1.5 \%$ fat, $22.0 \%$ fiber, and $26.5 \%$ ash.

${ }^{5}$ Dairy micro premix $2 \mathrm{X}$ is a product of Land O'Lakes (St. Paul, $\mathrm{MN})$.

${ }^{6} \mathrm{NFC}=100-(\% \mathrm{NDF}+\% \mathrm{CP}+\%$ ether extract $+\%$ ash $)$.

an electrically heated kettle (model TDC/TA/40, Groen Inc., Elk Grove, IL). Cream (1.82 kg) was separated by using an Elecrem model 1 separator (Elecrem, Vanves, France), adjusted to $30 \%$ fat with the skim milk, and stored overnight at $4^{\circ} \mathrm{C}$. The next day, the cream temperature was adjusted to $10^{\circ} \mathrm{C}$, and the cream was churned in a 4-L electric churn (Gem Dandy, Alabama
Manufacture Co., Birmingham, AL) for approximately $40 \mathrm{~min}$ (range 33 to $69 \mathrm{~min}$ ). Two milk samples from cows chosen for high-HPI milk fatty acid composition (one fed FO and another RSB) and one milk sample from a cow chosen for low-HPI milk (fed FO) failed to churn after $85 \mathrm{~min}$. The churn was operated at room temperature, and the cream temperature was allowed to rise from $10^{\circ} \mathrm{C}$ until the butter developed. To minimize texture changes, butter samples were kept in cold water within $2^{\circ} \mathrm{C}$ of the final churning temperature when performing the fat determination. The fat content of butter was adjusted to $80 \%$ by mixing water back into the butter using a heavy-duty mixer (Kitchen Aid, Troy, $\mathrm{OH}$ ) while keeping the speed as low as possible to prevent air from being incorporated into the butter. The fat content of butter samples was monitored by using Babcock tests (Milk Industry Foundation, 1949). The butter samples (520 to $580 \mathrm{~g}$ ) were stored at $4^{\circ} \mathrm{C}$ in closed plastic containers until further analyses.

\section{Fatty Acid Analysis}

For analysis of the fatty acid composition, we used milk (for choosing cows for the study), butter (for determination of treatment effects), and cream (for determination of treatment effects of the 3 milk samples that did not churn). The amounts of each sample were adjusted to have a fat content similar to that of $200 \mu \mathrm{L}$ of milk. The samples were suspended in $300 \mu \mathrm{L}$ of 1 butanol containing an internal standard comprising 0.4 $\mathrm{mg}$ of 11:0 and 0.4875 mg of 19:0 (Sigma Chemical Co., St. Louis, MO). Next, $500 \mu \mathrm{L}$ of additional 1-butanol and $50 \mu \mathrm{L}$ of acetyl chloride were added. The vial was filled with nitrogen gas, sealed, mixed on a Vortex mixer (Fisher Scientific, Pittsburgh, PA) for $2 \mathrm{~min}$, and heated on a steam bath for $1.5 \mathrm{~h}$. Then $3.3 \mathrm{~mL}$ of $6 \%$ aqueous $\mathrm{K}_{2} \mathrm{CO}_{3}$ and $630 \mu \mathrm{L}$ of hexane were added. The samples were mixed for $1 \mathrm{~min}$ and centrifuged for $15 \mathrm{~min}$ at 400 $\times g$ in a Centrific model centrifuge (Fisher Scientific). The lower, aqueous layer was discarded, and the hexane phase was washed with $3.3 \mathrm{~mL}$ of distilled water and centrifuged again. To remove butanol, $100 \mu \mathrm{L}$ of the hexane layer was applied to a 1-g silica cartridge (Chrom Tech. Inc., Apple Valley, MN) that had been washed with $5 \mathrm{~mL}$ of hexane. The cartridge was eluted with $5 \%$ diethyl ether in hexane. The first $2.3 \mathrm{~mL}$ of eluate were discarded, and the butyl esters were collected from the next $1.7 \mathrm{~mL}$.

The butyl esters were analyzed on a Hewlett-Packard 5890 (Avondale, PA) gas chromatograph equipped with a flame-ionization detector, a 3396A integrator, and a $30-\mathrm{m} 2330$ fused-silica capillary column with a $0.25 \mathrm{~mm}$ i.d. and $0.2 \mu \mathrm{m}$ film thickness (Supelco, Bellefonte, PA). The injector and detector temperatures were set at 
$250^{\circ} \mathrm{C}$, and the oven was held for 4 min at $150^{\circ} \mathrm{C}$, programmed at $20^{\circ} \mathrm{C} / \mathrm{min}$ to $230^{\circ} \mathrm{C}$, and held for $2.5 \mathrm{~min}$. The carrier gas was helium at $3 \mathrm{~mL} / \mathrm{min}$. The weight percentage of each fatty acid was calculated by using 11:0 for 10:0 to 14:0 and 19:0 for those longer than 14:0 as internal standards. External standards of known composition (GLC74 and GLC79, Nu-Chek Prep, Elysian, MN) were tested to verify the accuracy of the correction factors obtained with the internal standards. The HPI was calculated from the weight percentages.

\section{Textural Analysis}

For textural analysis, a TA-XT2i texture analyzer (Stable Microsystems, Surrey, UK) was used. Butter texture was analyzed at $4^{\circ} \mathrm{C} 1 \mathrm{wk}$ after manufacture. A conical probe with an angle of $40^{\circ}$ was advanced at $0.5 \mathrm{~mm} / \mathrm{s}$ until it reached $300 \times g$ of force, and the penetration distance was recorded as a measure of softness. Additionally, the speed at which the probe penetrated at $300 \times g$ of force for an additional $30 \mathrm{~s}$ was recorded as the creep compliance. The measurements were replicated 7 times for each sample, and the averages were used for statistical analyses.

\section{Statistical Analyses}

Statistical analysis was done by using the mixed models procedure (PROC MIXED) of SAS version 9.1.3 (SAS Institute, 2002). The fixed effects in the model were the HPI index of milk samples collected from the same cow prior to the feeding study (low HPI, high HPI), cow diet (control, FO, RSB), the interaction between HPI and diet, and replication (summer, fall). A completely unrestricted variance-covariance matrix was used to account for correlations between samples from the same cow. Effects of HPI (low vs. high), diet (control vs. FO, control vs. RSB), and the interactions between HPI and diet $(\mathrm{H} \times \mathrm{F}, \mathrm{H} \times \mathrm{R})$ were determined by using a 2 tailed $t$-test (ESTIMATE statement in SAS). Statistical differences were considered significant at $P \leq 0.05$ and were considered a tendency toward significance at $P$ $\leq 0.10$. The means and standard errors of the means presented in the tables are the least squares means and the largest standard error of the mean of the $6 \mathrm{HPI}$ by diet groups.

\section{RESULTS AND DISCUSSION}

Feeding supplemental FO or RSB increased the HPI of butter fat to higher values in cows that produced, prior to the feeding study, milk with high HPI values, compared with cows with low HPI values prior to the feeding study (Table 2). The type of supplement affected the fatty acid profile of the butter, with greater increases in linolenic acid (18:3) when cows were fed FO and greater increases in linoleic acid (18:2) when cows were fed RSB (Table 2). On average, butter HPI values were $13 \%$ higher from cows chosen for their high milk HPI than from cows chosen for their low HPI $(P=0.05)$. The HPI differences resulted mostly from increased proportions of oleic acid (18:1) in the butter fat $(P=0.06)$. A concern is that HPI values did not differ between the low- and high-HPI cows when fed the control diet (Table 2 ). The lack of differences in HPI values was limited to the first replicate, in which the time span between cow selection and the beginning of the feeding study was 6 wk, compared with $2 \mathrm{wk}$ in the second replicate. The effects of cow selection on butter HPI values were smaller than those previously reported by our group (Bobe et al., 2003; Chen et al., 2004) because cows were chosen from a smaller pool of cows $(n=25)$ that was less divergent in HPI values.

Butter texture was not significantly affected by cow grouping (Table 2). The penetration distance at $4^{\circ} \mathrm{C}$ was 7.3\% longer in cows chosen for their high HPI (penetration $=6.11 \mathrm{~mm}$ ) than in cows chosen for their low HPI (penetration $=5.69 \mathrm{~mm})$, which is consistent in direction but not in magnitude with our previous studies (Bobe et al., 2003; Chen et al., 2004). We hypothesize that the differences in butter fatty acid composition between the 2 HPI groups were insufficient to achieve differences in butter texture. Consistent with our previous studies (Bobe et al., 2003; Chen et al., 2004), this study indicates that cows can be grouped for milk fatty acid composition to produce butter with an improved HPI. In addition, this study suggests that feeding supplemental FO or RSB further improves the HPI values of butter fat from cows with a more unsaturated milk fatty acid profile.

Feeding cows $0.8 \%$ (on a DM basis) of additional unsaturated fatty acid-rich lipids in the form of FO or RSB increased the HPI values of butter (Table 2). Butter manufactured from the milk of cows fed an additional $0.9 \%$ of FO (on a DM basis) or $5 \%$ of RSB (on a DM basis $)$ had a $31.0 \%(P=0.02)$ and $33.5 \%(P=0.01)$ higher HPI value, respectively, than did butter from cows fed the control diet (Table 2). Donovan et al. (2000) reported similar increases in the HPI values of milk from cows fed an additional $1.0 \%$ of FO on a DM basis. Allred et al. (2006) reported larger changes in the HPI when additional lipids in the form of calcium salts of palm oil and FO plus extruded soybeans or soybean oil were fed to cows; however, the amount of supplemented lipids (around $2 \%$ on a DM basis) was much greater than in this study $(0.8 \%$; Table 1$)$. Our results indicate that adding even $0.8 \%$ of additional lipids in the form 
Table 2. Least squares means and significance of differences in fatty acid composition and texture of butter samples from cows with varying health promoting indexes (HPI) fed the control diet, supplemental fish oil (FO), or supplemental roasted soybeans (RSB)

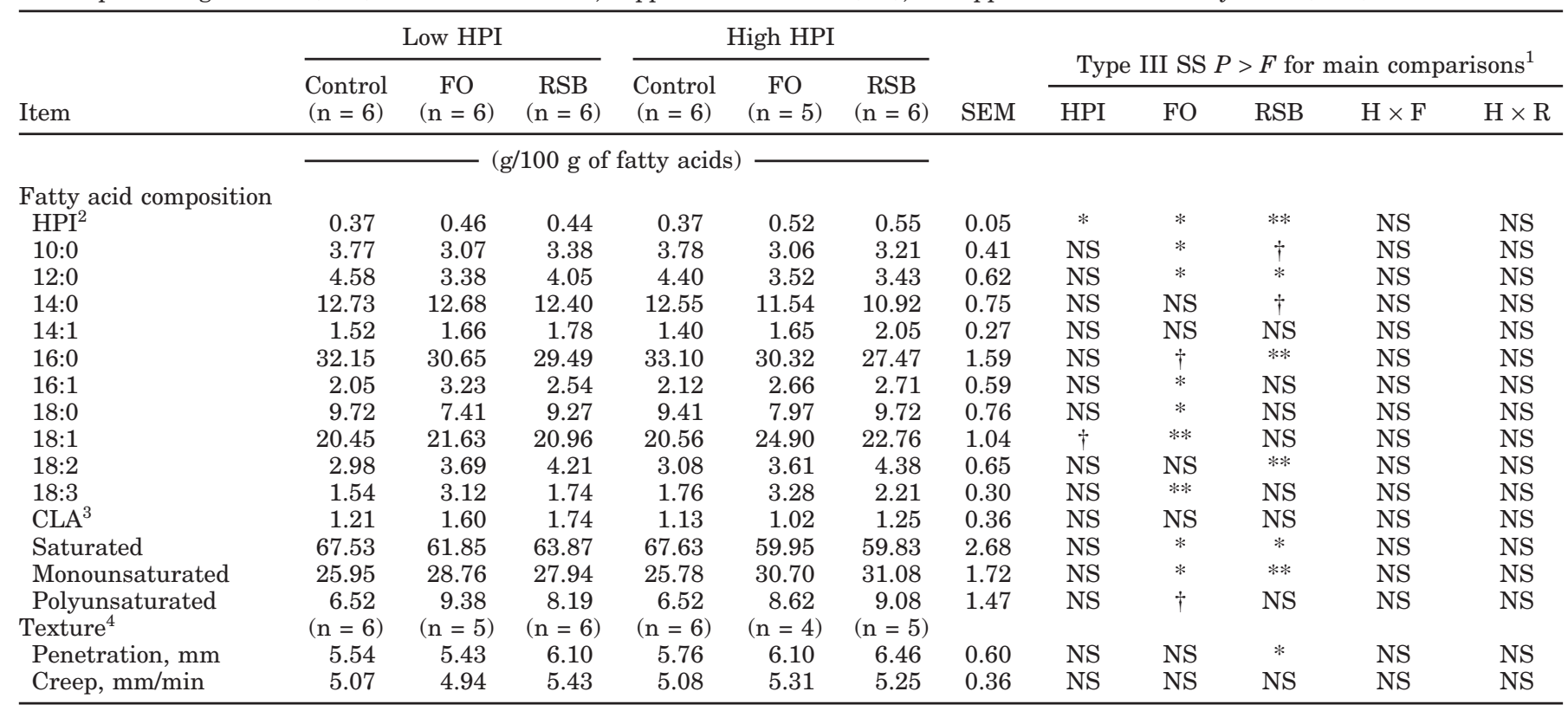

${ }^{1}$ HPI compares low- vs. high-HPI group samples; FO compares samples from cows fed fish oil vs. the control; RSB compares samples from cows fed roasted soybeans vs. the control; $\mathrm{H} \times \mathrm{F}$ compares the effect of feeding fish oil vs. the control in cows with low- vs. high-HPI milk fatty acid composition; $\mathrm{H} \times \mathrm{R}$ compares the effect of feeding roasted soybeans vs. the control in cows with low- vs. high-HPI milk fatty acid composition.

${ }^{2} \mathrm{HPI}=($ sum of $\%$ of unsaturated fatty acids $) /(\% 12: 0+4 \times \% 14: 0+\% 16: 0)$.

${ }^{3} \mathrm{CLA}=$ isomers of conjugated linoleic acid.

${ }^{4}$ Textural properties of butter were measured at $4{ }^{\circ} \mathrm{C}$ seven times for each sample with a TA-XT2i texture analyzer (Stable Microsystems, Surrey, UK).

$\dagger P \leq 0.10 ; * P \leq 0.05 ; * * P \leq 0.01$; NS: $P>0.10$.

of FO or RSB to the cow diet was sufficient to produce butter with a more health-promoting fatty acid profile.

Butter fat from the milk of cows fed supplemental FO or RSB was $9.9 \%(P=0.02)$ and $8.5 \%(P=0.02)$ less saturated, respectively, and $14.9 \%(P=0.02)$ and $14.1 \%(P=0.02)$ more monounsaturated, respectively, than was butter from cows fed the control diet (Table 2). Specifically, proportions of oleic $(P=0.01)$ and linolenic acids $(P=0.002)$ were higher in the butter fat of cows fed FO. In addition, proportions of linoleic acid $(P=$ $0.01)$ were higher and proportions of palmitic $(P=0.008)$ acid were lower in the butter fat of cows fed RSB than in the butter fat of cows fed the control diet (Table 2 ). Our results indicate that feeding supplemental FO, compared with feeding RSB, resulted in fatty acid profiles that were similar in the degree of fatty acid saturation and differed in the fatty acid profile. Similar changes in milk fatty acid composition have been reported for cows fed supplemental FO (Baer et al., 2001; Ramaswamy et al., 2001; AbuGhazaleh et al., 2002; Lacasse et al., 2002) or RSB (Weiss and Wyatt, 2003). Feeding cows supplemental FO or RSB at higher concentrations than those used in this study increased the susceptibility of dairy products to oxidized flavor development (Timmons et al., 2001; Lacasse et al., 2002). We did not evaluate sensory properties in this study. We would not expect detrimental effects of the feeding regimen on butter flavor because feeding supplemental FO or extruded soybeans at concentrations similar to or higher than those used in this study have been reported not to affect the flavor of dairy products (Lightfield et al., 1993; Baer et al., 1996, 2001; Ramaswamy et al., 2001).

Feeding cows $0.8 \%$ of additional lipids in the form of RSB but not of FO yielded significantly softer butter (Table 2). The penetration distance at $4^{\circ} \mathrm{C}$ was $11.1 \%$ longer in butter from cows fed RSB (penetration $=6.28$ $\mathrm{mm}$ ) than in butter from cows fed the control diet (penetration $=5.65 \mathrm{~mm} ; P=0.05)$. In comparison, in butter from cows fed FO, the penetration distance was with $5.77 \mathrm{~mm}$, only $2.1 \%$ longer than in butter from cows fed the control diet $(P=0.79)$. Consistent with these results, Ramaswamy et al. (2001) reported a significant increase in the penetration distance of butter at $4^{\circ} \mathrm{C}$ when cows were fed $10.6 \%$ of supplemental extruded soybeans but not when they were fed $2 \%$ of additional 
Table 3. Least squares means and significance of differences in DMI, milk yield, and milk composition of cows with varying health promoting indexes (HPI) fed the control diet, supplemental fish oil (FO), or supplemental roasted soybeans (RSB)

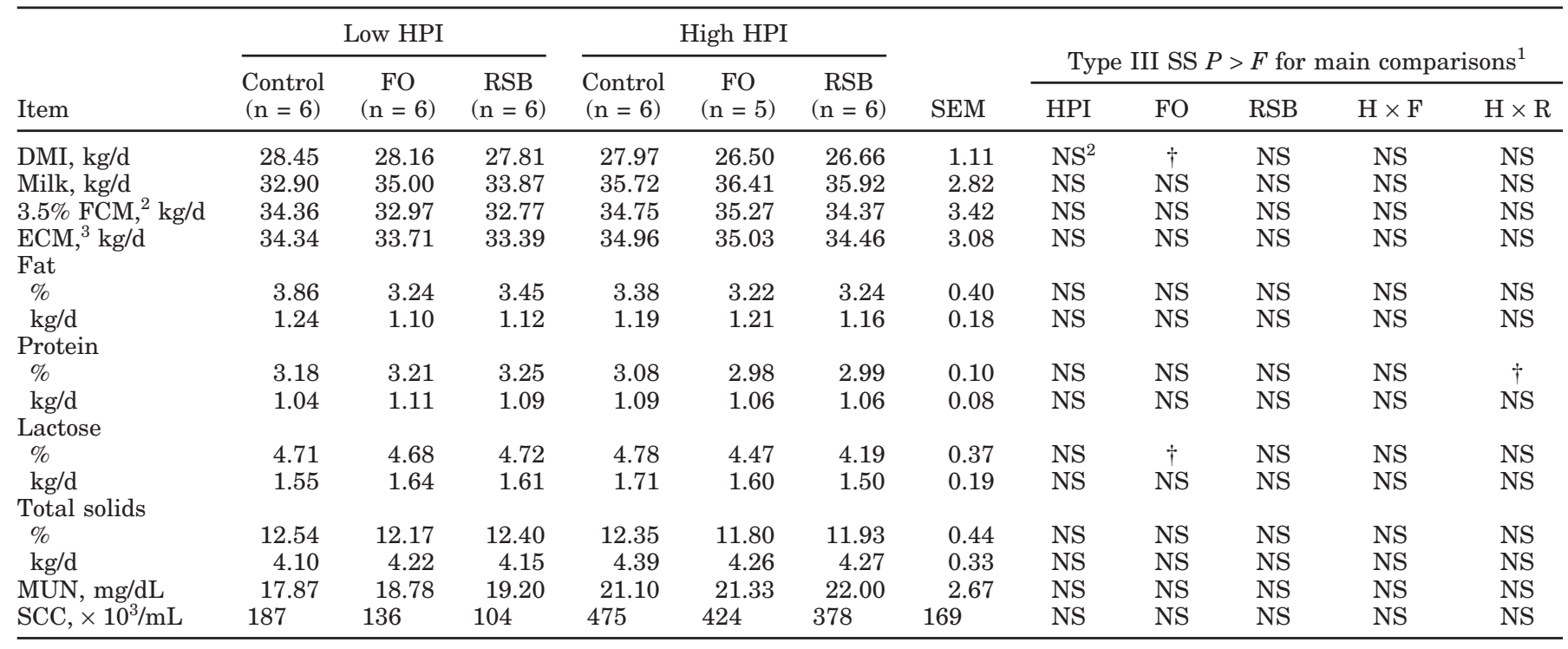

${ }^{1}$ HPI compares low- vs. high-HPI group samples; FO compares samples from cows fed fish oil vs. the control; RSB compares samples from cows fed roasted soybeans vs. the control; $\mathrm{H} \times \mathrm{F}$ compares the effect of feeding fish oil vs. the control in cows with low- vs. high-HPI milk fatty acid composition; $\mathrm{H} \times \mathrm{R}$ compares the effect of feeding roasted soybeans vs. the control in cows with low- vs. high-HPI milk fatty acid composition.

${ }^{2} 3.5 \% \mathrm{FCM}=[0.432 \times$ milk production $(\mathrm{kg} / \mathrm{d})]+[16.2 \times$ fat yield $(\mathrm{kg} / \mathrm{d})]$.

${ }^{3} \mathrm{ECM}=[0.372 \times$ milk production $(\mathrm{kg} / \mathrm{d})]+[12.95 \times$ fat yield $(\mathrm{kg} / \mathrm{d})]+[7.2 \times$ protein yield $(\mathrm{kg} / \mathrm{d})]$.

$\dagger P \leq 0.10$; $* P \leq 0.05 ; * * P \leq 0.01$; NS: $P>0.10$.

FO on a DM basis. In contrast with our results, Baer et al. (2001) observed a significantly longer penetration distance at $4^{\circ} \mathrm{C}$ in butter from cows fed $2 \%$ of supplemental FO. Although FO may have been less effective than RSB in changing butter texture under the conditions of our experiment, $25 \%$ of the butter samples from FO-fed cows were missing ( 2 butters did not churn and 1 cow became ill). Even so, the results showed that feeding $0.8 \%$ of supplemental lipids in the form of $5 \%$ of RSB induced beneficial changes in butter fatty acid composition and texture.

Churning times for the creams varied between 33 and $69 \mathrm{~min}$. Similar to our previous study (Bobe et al., 2003), cream from the high-HPI group had a numerically shorter churning time than did cream from the low-HPI group ( $42.4 \pm 3.1 \mathrm{~min}$ vs. $47.1 \pm 2.9 \mathrm{~min} ; P=$ $0.30)$. These results are consistent with the notion that cream that has a greater proportion of molten milk fat has a shorter churning time (Banks et al., 1989). The churning times of cream from cows fed supplemental RSB $(41.6 \pm 3.8 \mathrm{~min})$ or FO $(48.9 \pm 2.0 \mathrm{~min})$ did not differ significantly from the churning times of cream from cows fed the control diet $(43.7 \pm 1.9 \mathrm{~min})$, but they differed significantly from each other $(P=0.05)$. The type of lipid supplement has been reported to alter the churning time (Banks et al., 1989; Gonzalez et al., 2003). Furthermore, the milk fat of cows fed polyunsat- urated lipids required longer churning times to achieve the same consistency and texture as the control butter when prepared under conventional butter-processing conditions (Gonzalez et al., 2003). Thus, altering the processing conditions (i.e., lower churning temperature, lower blade speed, lower fat concentration of the cream, and addition of salt to the cream before churning) has been recommended for milk fat rich in unsaturated fatty acids (Buchanan and Rogers, 1973; Kieseker and Eustace, 1975; Wood et al., 1975). Cream with small fat globules or high viscosities is known to increase churning time (Hunziker, 1927). Thus, the longer churning time for FO creams may be the result of a smaller fat globule size or greater viscosity.

The highest HPI values in the butter fats were from cows chosen for their high-HPI milk fatty acid composition that were fed supplemental RSB (Table 2). Feeding supplemental RSB instead of the control diet to cows chosen for their high milk HPI increased the butter HPI by $48.5 \%$, compared with $18.6 \%$ for cows chosen for their low HPI. This change was achieved mostly through decreasing the proportions of myristic and palmitic acids (Table 2). Consistent with the effect on HPI values, the softest butter was produced from cows chosen for their high HPI milk fatty acid composition that were fed supplemental RSB (Table 2). No significant interactions between RSB feeding and HPI grouping 
were detected for butter fatty acid composition and texture (Table 2), which suggests that selecting cows with a high-HPI milk fatty acid composition in combination with feeding cows supplemental RSB acted additively to improve milk fatty acid composition and can be used as a tool to produce a more healthful butter fatty acid composition.

Neither cow selection nor cow nutrition significantly altered DMI, milk yield, and milk composition (Table 3 ). We did not observe, as had been reported previously (Bobe et al., 2003), differences in milk yield and fat percentages between cows chosen for their high and low HPI, because in this study all cows were already in positive energy balance and were of the same breed. In addition, selection for milk yield does not alter the milk fatty acid composition (Kay et al., 2005). Feeding supplemental FO at higher amounts $(>1.8 \%$ on a DM basis) decreases DMI, milk yield, and milk fat content (Donovan et al., 2000; Baer et al., 2001; Ramaswamy et al., 2001; Lacasse et al., 2002). Consistent with the results of this study (Table 3), lower amounts of supplemental FO were shown to decrease the milk fat content numerically but not significantly (Donovan et al., 2000). Similar to our results, feeding supplemental soybeans at amounts close to those in this study did not decrease the milk fat content (Banks et al., 1980; Murphy et al., 1990; Solomon et al., 2000; AbuGhazaleh et al., 2002; Weiss and Wyatt, 2003). Thus, our results indicate that feeding cows chosen for their high milk HPI $0.8 \%$ of supplemental lipids in the form of 5\% of RSB had no adverse effect on DMI, milk yield, and milk composition.

In conclusion, the current study demonstrates that selecting cows with a more health-promoting milk fatty acid composition and feeding supplemental RSB acted additively to produce a softer butter at refrigeration temperature with higher HPI values. Thus, a combination of cow selection and feeding supplemental unsaturated fats could be used as a method to produce butter and possibly other dairy products that have a consumerfriendly texture and a healthful fatty acid profile.

\section{ACKNOWLEDGMENTS}

The authors thank Swiss Valley Farms (Davenport, IA) for analysis of milk samples, Omega Protein (Hammond, LA) for donation of the menhaden FO, M. Reuber for technical assistance with the milk-processing equipment, and the managers and employees of the Iowa State University Dairy Breeding Research Facility (Ankeny, IA), in particular J. Dedrick and D. H. Kelley, for care of the cows and assistance in obtaining research data and milk samples.

\section{REFERENCES}

AbuGhazaleh, A. A., D. J. Schingoethe, A. R. Hippen, K. F. Kalscheur, and L. A. Whitlock. 2002. Fatty acid profiles of milk and rumen digesta from cows fed fish oil, extruded soybeans or their blend. J. Dairy Sci. 85:2266-2276.

Allred, S. L., T. R. Dhiman, C. P. Brennand, R. C. Khanal, D. J. McMahon, and N. D. Luchini. 2006. Milk and cheese from cows fed calcium salts of palm and fish oil alone or in combination with soybean products. J. Dairy Sci. 89:234-248.

Baer, R. J., M. R. Lentsch, D. J. Schingoethe, R. J. Madison-Anderson, and K. M. Kasperson. 1996. Characteristics of milk and reduced fat cheddar cheese from cows fed extruded soybeans and niacin. J. Dairy Sci. 79:1127-1136.

Baer, R. J., J. Ryali, D. J. Schingoethe, K. M. Kasperson, D. C. Donovan, A. R. Hippen, and S. T. Franklin. 2001. Composition and properties of milk and butter from cows fed fish oil. J. Dairy Sci. 84:345-353.

Banks, W., J. L. Clapperton, M. E. Kelly, A. G. Wilson, and R. J. M. Crawford. 1980. The yield, fatty acid composition and physical properties of milk fat obtained by feeding soya oil to cows. J. Sci. Food Agric. 31:368-374.

Banks, W., J. L. Clapperton, D. D. Muir, and A. K. Girdler. 1989. Whipping properties of cream in relation to milk composition. J. Dairy Res. 56:97-105.

Bobe, G., E. G. Hammond, A. E. Freeman, G. L. Lindberg, and D. C. Beitz. 2003. Texture of butter from cows with different milk fatty acid compositions. J. Dairy Sci. 86:3122-3127.

Buchanan, R. A., and W. P. Rogers. 1973. Manufacture of butter high in linoleic acid. Aust. J. Dairy Technol. 28:175-178.

Chen, S., G. Bobe, S. Zimmerman, E. G. Hammond, C. M. Luhman, T. D. Boylston, A. E. Freeman, and D. C. Beitz. 2004. Physical and sensory properties of dairy products from cows with various milk fatty acid compositions. J. Agric. Food Chem. 52:3422-3428.

Donovan, D. C., D. J. Schingoethe, R. J. Baer, J. Ryali, A. R. Hippen, and S. T. Franklin. 2000. Influence of dietary fish oil on conjugated linoleic acid and other fatty acids in milk fat from lactating dairy cows. J. Dairy Sci. 83:2620-2628.

Fernandez, M. L., and K. L. West. 2005. Mechanisms by which dietary fatty acids modulate plasma lipids. J. Nutr. 135:2075-2078.

Gonzalez, S., S. E. Duncan, S. F. O'Keefe, S. S. Summer, and J. H. Herbein. 2003. Oxidation and textural characteristics of butter and ice cream with modified fatty acid profiles. J. Dairy Sci. 86:70-77.

Grummer, R. R. 1991. Effect of feed on the composition of milk fat. J. Dairy Sci. 74:3244-3257.

Henning, D. R., R. J. Baer, A. N. Hassan, and R. Dave. 2006. Major advances in concentrated and dry milk products, cheese, and milk fat-based spreads. J. Dairy Sci. 89:1179-1188.

Hillbrick, G., and M. A. Augustin. 2002. Milkfat characteristics and functionality: Opportunities for improvement. Aust. J. Dairy Technol. 57:45-51.

Hunziker, O. F. 1927. Churning. Pages 274-293 in The Butter Industry. 2nd ed. Lakeside Press, Chicago, IL.

Jensen, R. G. 2002. Invited review: The composition of bovine milk lipids: January 1995 to December 2000. J. Dairy Sci. 85:295-350.

Kay, J. K., W. J. Weber, C. E. Moore, D. E. Bauman, L. B. Hansen, H. Chester-Jones, B. A. Crooker, and L. H. Baumgard. 2005. Effects of week of lactation and genetic selection for milk yield on milk fatty acid composition in Holstein cows. J. Dairy Sci. 88:3886-3893.

Kaylegian, K. E. 1999. The production of specialty milk fat ingredients. J. Dairy Sci. 82:1433-1439.

Kieseker, F. G., and I. J. Eustace. 1975. Manufacture by conventional churning of butter high in linoleic acid: Technology, physical properties and sensory evaluation. Aust. J. Dairy Technol. 30:17-22.

Lacasse, P., J. J. Kennelly, L. Delbecchi, and C. E. Ahnadi. 2002. Addition of protected and unprotected fish oil to diets for dairy cows. I. Effects on the yield, composition and taste of milk. J. Dairy Res. 69:511-520.

Lightfield, K. D., R. J. Baer, D. J. Schingoethe, K. M. Kasperson, and M. J. Brouk. 1993. Composition and flavor of milk and Cheddar 
cheese higher in unsaturated fatty acids. J. Dairy Sci. 76:1221-1232.

Mensink, R. P., P. L. Zock, A. D. M. Kester, and M. B. Katan. 2003. Effects of dietary fatty acids and carbohydrates on the ratio of serum total to HDL cholesterol and on serum lipids and apolipoproteins: A meta-analysis of 60 controlled trials. Am. J. Clin. Nutr. 77:1146-1155.

Milk Industry Foundation. 1949. Moisture, salt, and fat determination in butter and cheese. Pages 187-245 in Laboratory Manual: Methods of Analysis of Milk and Its Products. 2nd ed. Milk Industry Foundation, Washington, DC.

Murphy, J. E., G. P. McNeill, J. F. Connolly, and P. E. Gleeson. 1990. Effect on cow performance and milk fat composition of including full fat soyabeans and rapeseeds in the concentrate mixture for lactating dairy cows. J. Dairy Res. 57:295-306.

NRC. 2001. Nutrient Requirements of Dairy Cattle. 7th rev. ed. Natl. Acad. Press, Washington, DC.

Ramaswamy, N., R. J. Baer, D. J. Schingoethe, A. R. Hippen, K. M. Kasperson, and L. A. Whitlock. 2001. Composition and flavor of milk and butter from cows fed fish oil, extruded soybeans, or their combination. J. Dairy Sci. 84:2144-2151.

Rasmussen, B. M., B. Vessby, M. Uusitupa, L. Berglund, E. Pedersen, G. Riccardi, A. A. Rivellese, L. Tapsell, and K. Hermansen. 2006. Effects of dietary saturated, monounsaturated, and n-3 fatty acids on blood pressure in healthy subjects. Am. J. Clin. Nutr. $83: 221-226$
Sacks, F. M., and M. Katan. 2002. Randomized clinical trials on the effects of dietary fat and carbohydrate on plasma lipoproteins and cardiovascular disease. Am. J. Med. 113:13S-24S.

SAS Institute. 2002. SAS User's Guide: Statistics, Version 9.1. SAS Inst., Inc., Cary, NC.

Solomon, R., L. E. Chase, D. Ben-Ghedalia, and D. E. Bauman. 2000. The effect of nonstructural carbohydrate and addition of full fat extruded soybeans on the concentration of conjugated linoleic acid in the milk fat of dairy cows. J. Dairy Sci. 83:1322-1329.

Timmons, J. S., W. P. Weiss, D. L. Palmquist, and W. J. Harper. 2001. Relationships among dietary soybeans, milk components, and spontaneous oxidized flavor of milk. J. Dairy Sci. 84:2440 2449.

Ulbricht, T. L. V., and D. A. T. Southgate. 1991. Coronary heart disease: Seven dietary factors. Lancet 338:985-992.

Vessby, B., M. Uusitupa, K. Hermansen, G. Riccardi, A. A. Rivellese, L. C. Tapsell, C. Nãlsén, L. Berglund, A. Louheranta, B. M. Rasmussen, G. D. Calvert, A. Maffetone, E. Pedersen, I.-B. Gustafsson, and L. H. Storlien. 2001. Substituting dietary saturated for monounsaturated fat impairs insulin sensitivity in healthy men and women: The KANWU study. Diabetologia 44:312-319.

Weiss, W. P., and D. J. Wyatt. 2003. Effect of dietary fat and vitamin $\mathrm{E}$ on $\alpha$-tocopherol in milk from dairy cows. J. Dairy Sci. 86:3582-3591.

Wood, F. W., M. F. Murphy, and W. L. Dunkley. 1975. Influence of elevated polyunsaturated fatty acids on processing and physical properties of butter. J. Dairy Sci. 58:839-845. 